\title{
ARCYBISKUP JÓZEF BILCZEWSKI JAKO ARCHEOLOG CHRZEŚCIJAŃSKI (W 60 rocznicę śmierci)
}

T ubiegłym roku minęło 60 lat od śmierci jednego z pierwszych t największych polskich znawcóm archeologil chrześc1jańskiej, lwowskiego metropolity obrządku lacińskiego, arcybiskupa Józefa Bilczewskiego. Zmarł bowiem 20 marca 1923 roku we Lwowie. Wtedy to wymornie napisal o zmarłym arcypasterzu jego wychowanek, powiernik 1 przyjaciel ks. profesor Mleczysław Tarnawski: "W usługach Kościoła 1 0jozyzny strawiz swe siły 1 zdrowie. Nazwiskiem swolm wypełniz ćwlerćwiekowa historie Kościoła 1 Polski tak chlubnie, ze niewiele inion takich wyliczą dzieje naszych czasóv"1. Odszedz od nas "prawdziwy olbrzym unysłu, serca 1 zasług" 2 .

Dzinne są zamiary 1 plany Boże, które człowlek nie zawsze moze zrozumié́. Ks. Józel Bilczewski przyjął święcenia kapłańskie w Krakowie. Niewielkie nadzieje zapewne rokował, po ludzku sądząc, młody plastun Boży, skoro podczas áwięceń kapłańskich, które przyjmował na siedząco, zemulaz z powodu ryczerpania. ${ }^{3}$

Wet jednak po wyświęcentu wyznal otwarcie, te pragnąl tylko jednej rzeczy na zlemi, a mianowiole "Katedry św. Teologi1, po niej zaś juź tylko szcześliwej ámierci w cell zakonnej"4. Przez tę wypowledź odsłantał ten młody kapłan szczerze niek tamany zapał 1 pęd do wiedzy teologicznej. Bóg jednak poklerowal inaczej jego marzeniam1 1 tęsknotami ducha, doprowadzając do tego, ze stał się on "chluba w dziejach Episkopatu 1 Kościołan"

Na temat arcýbiskupa Józefa Bilczewsklego pisano juz wlele " polstiej historiografi1 ${ }^{6}$. W niniejszym artykule pragnieny przypo-

1 M.Tarnawsk1, Arcybiskup Józet Bilczewsk1. Krótk1 zarys zycia 1 prac, Lwór 1924, 5.

2 Tamze 5 .

3 Tanze 8 .

4 Tamzo 8.

5 A.Medyrisk1, Ks.Arcyb1skup Dr Bolesław Twardowsk1 1886-1936, Lwów

6 Blbllografle o aroyblskuple Józefle Bllozewskim zebrał 1 opracowaz 
mnieć z racj1 obchodzonej w ubiegłym roku 60 rocznicy śmierci, Jego zasługi w badaniach nad archeologla chrześcijańską w Polsce, które rozsławiły jego imie.

Przyszedł na ślat $26 \mathrm{kwletnla} 1860 \mathrm{r}$. We wsi Wilamowice, starej osadzie średniowlecznej, przynależnej do diecezji krakowskiej. Rodzicami jego byl1: Franciszek 1 Anna z Fajkiszóm. Droga przyszłego metropolity wlodła poprzez szkoły podstawowe wilamowicach $1 \mathrm{Ke}-$

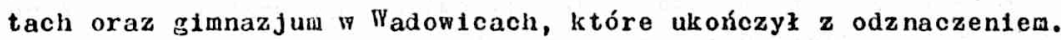
Studia teologiczne odbywał $\$$ Krakowle /1880-1884/, w Wiedniu/18841886/, W Rzymle /1886-1888/ 1 częśc1owo w Paryzu w Instytuc1e Katolickim. Doktorat z teologil uzyskał w 1886 roku w Uniwersytecie Tiedeńskim, na podstawie dysertacji z zakresu dogmatyki p.t. "Deus est Creator mund $1 " 7$.

Pobyt w Rymie okazał sle dla ks. Józela Bilczewskiego błogosławiony, gdyż pozivolił mu zrozumies "tajemnicę wielkości Kościoła" 1 ulec "fascynacji starożytności chrześcijańskiej, a szczególnie katakumb" ${ }^{8}$. W Wiecznym Mieście mieszkał Wolegium Polskim, zdobyrając wykształcenie archeologiczne pod kierunkiem znakomitego mistrza 1 uczonego, Giovanniego Batt1sty de Rossi, wybitnego archeologa, "twórcy archeologi1 chrześcijańskiej", który darzyz go szczerą przyjaźnia ${ }^{9}$. Omawtając we wspomntentu pośmiertnym dorobek naukowy swego Mistrza pisał, że "rozsławiło sie szeroko 1 daleko po śmie-

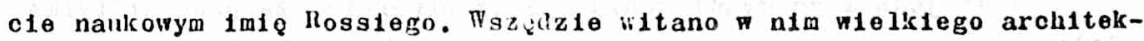

0. Romuald Gustaw, w: Ilagiografia Polska, Poznań 1971, t.1, 133139.

7 Por. Wydzial Teologiczny Uniwersytatu Jana Kazinierza we Lwowie 1918-1933, Livów 1934, 32; K. Lewloki, Habilitacja ks. Józefa Bilczersklego w Uniwersytecie Jaglellońskim w roku 1890, "Nasza Przeszłość "36/1971/261-270; Bp W. Urban, Sługa Boży Józef Bilczeisk1 Arcyb1skup-Setropol1 ta Lwowski 1860-1923, Wrocław 1977, 10; M.Tarnawski, Arcybiskup Józef Bilczewski, dz.cyt., 10; M. Krawlecki, Ks. Józef Bilczewski, archeoloǵ, badacz wczesnochrześcijariskiej lkonograf11, SACh 2/1980/ 163-195.

8 Bp M.Rechowicz, Sługa Bozy Arcybiskup Józef Bilczerski /w 60 roczniç śmierci/, TP $37 / 1983 / \mathrm{nr} 25,7$.

9 W. Urban, Sługa Boży Józep Bilczewski, dz.cyt.j 11. 
ta, geografa $i$ nowego Kolumba Rzymu podzieinnego, który odkryciami swyml zbliżył nam wiek żłoty męczenników, 1 owa najpiękniejszą dobę zycia Kościoła, kiedy wedle wyrażenia św.Hieronima do Demetriady, jeszcze ciepła była co dopiero przelana krew Chrystusa - quando calebat adhuc Domini nostri cruor" ${ }^{10}$. W Rzymie zebrał Ks.Bilczewsk1 bogaty materiał źródłowy z zakresu archeologil chrześcijańskiej, pomnazając go jeszcze później w bibliotekach 1 muzeach paryskich.

Tynikiem $t$ ych studiów 1 zainteresowán archeologicznych były dwa dzieła, które przyniosły mu sławę naukowa. Pierwszym z nich byza rozprawa habilitacyjna dedykowana ks. Albinowl kard. Dunajewskiemu $"$ "dowód najgłębszej czci 1 wdzlęczności jako owoc mozolnych badań w katakumbach"11 pt." Archeolog1a chrześc1jańska wobec history1 Kośc1oła 1 doginatu" /Krakóv 1890, s.XIX + 337, 8 1lustr., 2 tabl./, którą przedstawił na Uniwersytecle Jaglellońskim. Na wykład próbny władze uczelni wyznaczyły mu temat: "0 1le archeologia jest źródłen dogmatycznym dla eschatologil"12. Wkrótce zostala ona równieź przetłumaczona na jezylk czeski przez Józefa Tumpacha ${ }^{13}$.

Temat swego dzieła, Jak stwierdza jeden z recenzentów, oparł B1lczewsk1 zarówno "na odkryclach katakumbowych Jak 1 na 1 nnych wykopaliskach" pomnikach grobowych plerwszych chrześc1jan, zaznaczając jednak, że praca jego "różni się pod tym względea od wszystkich podręczników archeologicznych, ze nie zajmuje się opisem katakuıb, ale wyłącznie ma na oku korzyśo1, Jakie archeologia przynosi dla historil chrześcijaństwa 1 dogmatun ${ }^{14}$; archeologia jest dla niego źródłem historil Kościoła 1 doginatyk1. Inny natomiast recenzent ks. Eustachy $S_{k}$ rochowski, choć wytknąz autorowi pewne usterki, to jednak podkreślił, ze widzi w tym dziele "miłość nauki 1 ten św1ęty ogień, który raz rozbudzony, prędko nie gaśnie"15.

10 Dorobek nauk owy Iossiego, PP 12/1895/ t.47,76.

11 J.Latosiński, Monografla miasteczka Wilamowic na podstaw1e źródeł autentycznych, Kraków 1909, 330-331.

12 K.Lew1ck1, Habilltacja, art.cyt. 266; W.Urban, Sługa Boży Józef Bilczewski, dz.cyt. 13.

13 Archeologie Kř̀estanská ve službach dějin cirkevnich a vèrouky, Praha 1898.

14 K.Lewick1, Habilitacja, art.cyt. 264-2"5.

15 PP 8/1891/t.29,93-97; GKS 5/1897/440-444. 
Drugz praca, rozsławiająca $1 \mathrm{mig}$ Bilczewskiego w dziedzinie archeologi1 była rozprawa: "Eucharyst1a w swietle najdawniejszych pomników plśmlennych, ikonograflcznych 1 eplgrafleznych" /Kraków $189 \varepsilon$ s.XIV + 328/. Przyniosła ona autorow1 w $1897 \mathrm{r}$. nagrode Kralsowskiej Akademil Uniejętności 1 dalszy rozgłos w świecie nauki. Jej recenzenci podnosili, że tę "płękną, powazna, znakomitą" pracę o Eucharystil, powinien znać każdy jej czciciel, aby w opisie łamania chleba stale dostrzegać Boską 0sobę ofiarujizcego 1 ofiary ${ }^{16}$. Równiez 1 ona ukazała się w tłumaczentu czeskim wspomnianego już Józefa Tumpacha ${ }^{17}$. Ks. Józef Bilczewski nie spoczął jednaik na laurach, ale dalej prowadził badania w dzledzinie archeologi1. Dzięki nim zyskał u potomnych opinie, że prace jego z zakresu archeologil wydane przed rokiem 1900 weszly na trwałe do naukowej literatury archeologicznej "18.

Dnia 1 lutego $1891 \mathrm{r}$. ks. Bilczerski wszedz w podwoje Un1wersytetu we Lwowle w charakterze profesora ${ }^{19}$, skąd wkrótce w 1900 r. został prekonizowany na stolice metropolitalnz 1 stał sie jednym "z największych biskupów swojej doby"20. Zauwazono, ze $1 \mathrm{mi}$ a arcybiskupa Józefa Bilczerskiego "przenikało na wskroś dusze polskiego narodu"21. Kówniez jako profesor nie załował trudu 1 dawał do rąk chętnych czytelników owoce swolch naukorych mozołów 1 pośipięceń.

Do dalszych jego archeologicznych prao zallczamy: "Maniusz

Acyliusz Glabryo, Studiug archeologiczne z pieriszych czasów chrześz cijaristira"22. Dontosla role czystego życia zaalcentowal w pracy "Dzlewice Boru poświecone w pierwszych wiekach Koścloza" 23, oddajac

16 Por. recenzje ks.M.Morarskiego, PP 16/1899/ t.64,97-101.

17 Eucharistie ve sẻte nejstaršich památek literarnich, 1konograflckých a eplstografickych, Praha 1910.

18 K. Lowicki, Ilabilitacja, art.cyt. 270; K.Majewski-H.Bittner, Materiały do bibliografí archeologil B́ródzlemnomorskiej za lata 1800-1951, Warszara 1952 /pozycje Bilczewsklego nr 4,5, $131,201,898,1953 /$.

19 Arohiwum Kuril Letropolitalnej w Krakowie. Personalia ks. Józela Bilczewskiego.

20 "Apostolstwo Chorych" 44/1973/ nr 9,1-4.

21 J.Latosínsi, Monografia, dz.cyt. 456.

22 "Kwartalnik Historyczny" 6/1892/465-497.

23 PP $9 / 1892 / t .35,1-37$. 
hołd czystośc1 dzlewio chrześc1jańskich Bogu poświęconych, obejmujacej cała istote człowieka. W innej rozprawie pt. "Znaczenie badari katakumborych dla historil sztuki i religil" 24 pisal z przekonaniem, te cmentarze chrześcijańskie stanowią "bogata kopalnie da historil sztuki 1 historil dogmatón chrześcijańskich" ${ }^{25}$.

Szereg pięknych myśl1 mypowiedzlał ks. Bllczewski na temat Symbolu Apostolskiego, na którym "ucywilizowały slę ludy nowozytne: na nim, niby na chlebie powszednim, urosil nasi przodkowie". Dla ojoów Kościoła był on swoista pieśnia zbawienta. Jego opracowante przedstawil w rozprawie pt. "Geneza i historya Symbolu Apostolskiego", opublikowanej w dwóch częściach "I. Symbol od w. XIX rstecz do poczatków $n$. IVn" 26 "II. Symbol w trzech plerwszych wiekach" Tenze Symbol jeat jego zdaniem "kluczem, którym roztwiera sie duszy podwoje, aby mejóć mogła " światłość Chrystusa" ${ }^{28}$. Autor kończy swoja wnikliwa rozprawe słowaral modlitwy éw.Hilarego z Polt1ors: "Zachowaj, błagam, o Boze, tej wiary mojej niepokalane wyznanie, 1 az do ostatniego tchu zycia mego zostaw mej duszy to gorace pragnienie posiadania zawsze tego, co wyznałem w symolu wego odrodzen1 $a^{29}$.

Swego mistrza 1 przewodnika w odczytywaniu katakumb uhonorował Bllczewsk1 w specjalnej rozprawce pt. "Glovanni Battiota de Rossin30. Jemu tez poświęcil inny artykuł pt. "Dorobek naukowy nosBlego" 31 przypoininająo $w$ nlm przede wszystkim trzytomowe wiokopomne dziełko swego mistrza "La Homa sotterranea orlotiana" Moma 1864$-1867-1877$ / oraz jego inne naukore przeds1ęwzięc1a $a^{32}$.

24 "Blblloteka Warszawska" 4/1893/496-509.

25 Recenzja A.ldiodońskiego, "Kwartalnik H1storyczny" 10/1896/ 334335.

26 PP 11/1894/t.42, 153-173.

27 PP 11/1894/t.42, 363-378.

28 J.Bilczewsk1, Geneza 1 historya Symbolu Apostolskiego, PP 11/1894, t.42, 155 .

29 De Trinitate XII, 57, PL 10,471-472.

30 "Przegląd Polski" 27/1892-1893/t.107, 587-600.

31 PP $12 / 1895 / t .47,73-85,220-247$.

32 W r. 1863 Rosei rozpocząz wydawanie perlodyku "Bolletino d1 aroheologia criatiana", redagowanego przez niego od poczatku do końca zyola, aby "dostarczać spragnionym nowośc1 1 szybkich informaoj1 o zdobyczach archoologil". Do Innych jego wybitnych dziel nalezą: "Musalo1 delle chiese di Roma anteriori al secolo 
Do modnej wówczas problematyki katakumbowej powróc1ł nasz polski archeolog we wntkliwym artykule pt. "Nowe odkrycia w katabkumb1e św.Pryscyl11" "33 ; który ukazał s1ę równoczé́nie zatytuzowanej "Katakumba św. Pryscyll1 1 jej na.jważniejsze pomniki" /Kraków $1895 / 34$. Wapominanaz zaś wcześniej starozytną tematykę eucharystyczna podejmował on jeszcze dwukrotnie: w artykule pt. "Cześó Najśwletszego Sakramentu w clagu wieków" 35 , or az $w$ obszerniejszym opracowaniu pt. "0 chloble 1 winie do Eucharygt11 uźywanym. /Studium historyczno-archeologiczne/36. If swych archeologicznych dociekaniach nie pominąz równiez tak waźnej instytucj1 jak małzeństwo 1 rodzina, ale w oparciu o starozytne źródła materialne ukazaz ich role " zyciu ludzkich społeczeństw 1 narodón wartykulo pt. MMałzeństwo on dawnych chrześcijańskich pornikach. Studium dogmatyczno-h1storyczne" ${ }^{37}$. Nalezy tu jeszcze przypomnieć, ze ks. Józef Bilczewsk1 już wczośniej, niejako tytułem próby, ogłosiz drukiem $1890 \mathrm{r}$. pewne wyjatki z przygotowywanej habilitaoyjnej monograf11 "Archeologia chrześcijańska", a mianowicle: "Sztuka w plerwotnym Kośclele" 38 oraz "Połozenie prawne chrześcijan w państwie rzymskim" w trzech plerwszych w1ekach" 39 .

Ks. Bllczewski zalnteresowal się równ1ez specjalnie okresem prześladorań za cesarza Deojusza 1 Dlokleojana, klody to w pewnych kregach osłabła pręznośd chrześc1jan w dziedzinie zycia wiary 1 poJawiło się wielu odstępcói określanych mlanem "lapsi"/upad11/.Zają sie on nimf oraz stanowiskiem Kościola wobec tego problemu ojalnej monografil pt. "Nowe akta do history1 przesladonań 1 praktyk pokutnych" /Lwów 1900, ss.46/. Jej recenzent kв. Józef Gliwa pod-

XV", Roma 1872-1894 oraz ukończone tuz przed śmiercią/20 IX 1894 / "Martyrologlum IIIeronymianum ad fidem codicum addictis prolegomenis", Bruxellis 1894.

33 PP 12/1895/ t.45, 226-243, 378-400.

34 Recenzje tej pracy napisal ks.Eustachy Skrochowski, GK 3/1895/ 304-305.

35 GK 5/1897/ 277-279, 295-298, 308-309, 315-316, 329, 331, 338-340, 347-348.

$36 \mathrm{PP} 14 / 1897 / \mathrm{t} .54,325-343, \mathrm{t} .55,38-52$.

37 PP $16 / 1899 / \mathrm{t} .62,1-19$.

38 PP $7 / 1890 /$ t.27, 153-173, 327-362.

39 PP $T / 1890 / t .25,346-361, t .26,59-74,178-192$. 
kreślał, ze jest to "praca wprawdzle niedługa, ale bogata treścia; interesujaca, bo rzuca nowy promień światła na niedostatocznie jeszoze zbadane pierwszo wieki ohrześcijaństwa"40.

Obok specjalnych studiów ks. Bilczewski pisał pachowe recenzje zagranicznych publikacjl z dzledziny archeologil 1 sztuk1 wczesnochrześcijańskiel. Nalezały do nich: Joseph Wilpert, Prinoipienfragen der christlichen Archtologie mit bosondorer Berlackichtigung der Forsohungen von Scultre, Hasenelover und Achelis, Freiburg im Br. $1889^{41}$; Die Katakombengemalde und ihre alten Copion. Eino 1konographische Studie. Wilpert Joseph. Mit 28 Tafeln im Lichtdrucke. Freiburg Im Br. 1891 42 ; Fractio panis. Die Hltosto Darstellung des oucharistischen Opfers in der "Capella Graeoa". Endeckt und orlatert von Joseph Wilpert. Mit 17 Tafeln und 20 Abbildungen Im Text, Frelburg Im Br. $1892^{43}$; H.Grisar, Un prétendu trésor sacré des premièrs siècles, Rome $1895^{44}$; L.Atzberger, Geschichte dor christlichen Eschatologie innerhalb der vornicanischen Ze1t, Freiburg im Br. $1896^{45}$; F.X.Kraus, Geschichte der christilichen Kunst, Frelburg 1896, Bd. $1^{46}$; Die Malereien dor Saoramentscapellen in dor Katakombe dos hl.Caliztus. Von Joseph Wilpert. Nit 17 Illustrationen, Freiburg im Br. $1897^{47}$; G.W.Wilpert, Un oapitolo di storia del vestiario, Roma $1898^{48}$.

Jak nas informuja źródła lwowsk 1 archeolog dzielit ale równiez swoja wiedza z ówozesnym społeczeństwem poprzez publiczno odczyty popularyzacyjne. Należy do nich wykład z $1893 \mathrm{r}$. pt. "O znaczeniu apologetycznym archeologif w czasach dz1siejszych", wygłoszony na wiecu katolickim $\mathbf{w}$ Krakowio. W Czytolni Katolickiej we Lwowle mówił w $1894 \mathrm{r}$ "O rzymskich katakumbach", a v $1897 \mathrm{r}$. "O kiszy świetej w II w1eku". W tymże samym roku wystapiz na Uniwersytecie we Lwowio z odczytem pt.

10 PP $17 / 1900 / t .68,432-434$.

41 PP $7 / 1890 / t .25,115-118$.

42 PP $8 / 1891 / t .32,273-277$.

43 PP $13 / 1896 / t .49,455-459$ oraz CK $4 / 1896 / 137$.

44 PP 12/1895/t.48,449-455.

45 PP $14 / 1897 / t .55,140-142$.

46 PP $14 / 1897 / t, 54,440-444$.

47 PP $15 / 1898 / t .58,267-271$.

48 PP 16/1899/ t.62,115-119. 
"0 nagrobku Abercjusza z Hierapol1g", w ramach zạ́ powszechnych wykładów uniwersyteckłch wygłosił w $1899 \mathrm{r}$. szé́ć odczytón na temat: "Wlara 1 zycie plerwszych chrześcijan w śwletle pomników katakumbowychn"49. Wreszcie jako arcybiskup lworski wygzosiz po niemiecku podczas Kongresu Eucharystyoznego we Wiedniu /12 IX $1912 /$ odczyt pt. "Obrazy eucharystyczno $w$ katakumbach rzymskich" 50 .

2 chirila otrzymania w 1900 roku nominacj1 na metropolite wo Lwowie, wysiłki życlowe Józefa Bllczewsklego musiaky z koniecznośc1 wejóć na inne tory, a mianowicle na duszpasterskie. Oozywície, ze przy pełnientu tak bardzo odpowiedzlalnego 1 pracochłonnego urzedu arcypásterskıego, nie mógł śnaleźć czasu na kontynuowante tworzenla 1 pisania prac naukowych, ale 1 wówczas, przy tylu obowiázkach, często powracal do umiłowanej archeologil, b́ledził jej rozwój, a nawet zbierał klisze 1 materlały z myśla o nowym wydaniu swego dzleka "Archeologia chrześcijańska". Nic więc dziwnego, zo jego biograf ks.Mleczysław Tarnawsk1 o nim napisał, ze "zachowal cala dusze profesorska do koúca życia" 51 .

Bp W1noenty Urban - Wrockaw

DE JOSEPHO BILCZLISSK ARCIEOLOGIAE CHISTIANAE SCIUUTATORE /Summarium/

Josephus Bilczewski dioccesis Cracoviensis sacerdos, anno 1884 ordinatus, maxima cun diligentia studils theologicis praesertim archeologiae christianae additus erat. Hoc in artioulo sua soient1fica opera archeologica enumerantur atque recensentur.

49 Por. J.Latosísk1, Monograf1a, dz.cyt, 331; N.Tarnawsk1, Arcyb1skup Józef Bilczerski, dz.cyt., 14; W. Urban, Sługa Bozy Józef Bilczewski, dz.cyt., 24.

50 Przekład tego odczytu moźna znaleźd wśród jego "Listón Pasterskich", Lwór 1922, t.2, 295-312 lub wego dziele: Bóg-miłośd, Luó́ 19́13, 141-162.

51 M.Tarnawsk1, Arcyb1skup Józef Bilczewsk1, dz.cyt., 120. 